\title{
Research Trends in Spanish Psychology (1989-1998)
}

\author{
Juan Fernández \\ Complutense University of Madrid
}

The aim of this paper is to present the design of a study for the intemational dissemination of the research trends of Spanish psychology during the last decade (1989-1998). For this purpose, the international databases MEDLINE, PsycLIT, and ERIC were used, as well as some national databases such as ISBN and PSICODOC98. In addition, letters requesting ratification or rectification of the data were sent to 1,395 faculty members who had tenure at that time in Spain. Data about the specific context of the psychology faculties and the more general context of the Spanish university are also provided. The concrete results of the research trends of the different areas are analyzed in detail in the articles of this special issue.

Se presenta aquí el diseño de un trabajo que pretende dar a conocer internacionalmente las líneas de investigación de la psicología española de los últimos 10 años (1989-1998). Se han manejado para ello las bases de datos internacionales MEDLINE, PsycLIT y ERIC, junto con algunas de ámbito nacional como la del 1SBN y la PSICODOC98. Además, se han enviado cartas de ratificación o rectificación de lo obtenido a los 1,395 profesores universitarios numerarios existentes en esos momentos en España. Se recogen aquí, igualmente, datos tanto del contexto especifico de las facultades de psicologia como del contexto más general de la universidad española. Los resultados concretos de las líneas de investigación en función de las distintas áreas de conocimiento aparecen analizados pormenorizadamente en los distintos artículos de este monográfico.

Correspondence concerning this article should be addressed to Dr. Juan Fernández, Departamento de Psicología Evolutiva y de la Educación. Facultad de Psicología. Campus de Somosaguas. 28223 - Madrid (Spain). E-mail: psevo01@sis.ucm.es 


\section{Research Trends: Their Conceptualization}

We wish to make clear from the start what we consider research trends in this special issue: These are defined as being made up of at least five specific publications (journal articles, books, or book chapters) about the same psychological topic or theme, during the interval between 1989 and 1998. We decided to choose this last decade because, as Dyson (1997) -inspired by Shakespeare- pointed out, 10 years is the normal horizon of human activities and is a typical temporal scale for a scientific revolution.

Each faculty member - "Catedrático" (Full Professor) or "Titular" (Tenured Professor)- from the faculties or university schools who satisfied these minimum requisites, by right, would be listed as the author of a research trend. Circumstances such as the members' scientific school, the perspective adopted, the methodology employed, the Spanish university to which faculty members belonged, or theit possible political ideology were of no consequence in this decision. Thus, we attempted to eradicate favoritism towards friends or others who share our perspective, recently denounced by Baltanás (1999) in Nature as unfortunately very frequent within the university institutions.

With this purpose in mind -to detect the research trends-, a series of works that, regardless of their undoubted interest from other viewpoints (popularization, theoretical reviews, students' aid, social or political consequences, etc.), but which did not focus on research or were only a formality to gain access to a certain academic category, were not taken into account. For example, the following type of works were not included:

a) handbooks, textbooks, and similar works;

b) congress proceedings, seminars, meetings, or any type of conferences, etc.;

c) doctoral dissertations;

d) articles published in newspapers, or in professional or local journals;

e) popularization works (articles, books, book chapters, etc.);

f) translations of other authors' books or articles;

g) prologues, introductions, or epilogues;

h) reviews or commentaries of books.

Nevertheless, in addition to the research trends, it seemed appropriate to include a study of practical or professional psychology, to compliment the viewpoint offered from academic psychology. This work was carried out by the principal authorities of the Colegio de Psicólogos [COP; Official College of Psychologists, also denominated The Spanish Psychological Association] from the national territory (see the last article in this issue).

\section{Procedure}

The first step in this conjoint research was to ask the academic authorities from the Consejo de Universidades (Council of Universities) to send us a complete list of all the tenured professors ("catedráticos" and "titulares") from all over Spain, both from faculties and from university schools. The most recent list from this academic institution was dated April 7, 1999, which was the list we used. The data extracted from the six officially established areas in Spain are displayed in Table 1.

In view of these data, the following decision was made: to carry out this work using the total of tenured faculty members, both from faculties and from university schools, although we were aware that the circumstances of the academic contexts of these two institutions have been historically different. The atmosphere in the faculties has generally been more favorable for research (more tradition, culture, and funding) than that of the university schools. Also, in the case of the tenured university school professors, the university law does not designate research as one of their basic functions. Obviously, this must be taken into account when comparing the scientific production among the different areas, because the number of these professors is so variable among the areas that it is very difficult if not impossible, to find some significant results in this kind of study.

The second step was to search in the five databases (MEDLINE, PsycLIT, and ERIC -international- and ISBN and PSICODOC98 -national) and locate the material that each and every one of these professors had published. This first search was carried out by other persons ${ }^{1}$ than the authors who sign the corresponding articles, with the aim of avoiding as much as possible any bias due to friendship or possible pressure derived from belonging to the same area. During this search, we were able to see that databases are far from perfect, because not all the works published by professors in journals that were supposedly listed, did, in fact, appear in these databases. To date, we have no explanation for this. In addition, the introduction of each professor's publications, either in the same or in other databases, had been carried out differently: by the first last name in some cases, by the second last name in others, occasionally by the first name, and at other times according to an obvious error in the denomination. Sometimes, it was impossible to differentiate the publications of several professors because they shared the same initials and same first last name.

The initial results were handed over to the people responsible for each article so they could carry out the pertinent corrections and refining. At this point, the different authors performed their functions as they saw fit. Some re-examined each and every one of the contributions of the professors from

1 At this point, we wish to offer our most sincere thanks to Professors Ángela Conchillo, María Ángeles Quiroga, and María Luisa Sánchez-Bernardos and to the scholarship holder, David Villar Sánchez de Molina. In addition, we must acknowledge that this work would not have been possible without the support and encouragement of the former Dean of the Psychology Faculty, Dr. Lucila González Pazos. 
Table 1

Psychology Faculty Members from Spain

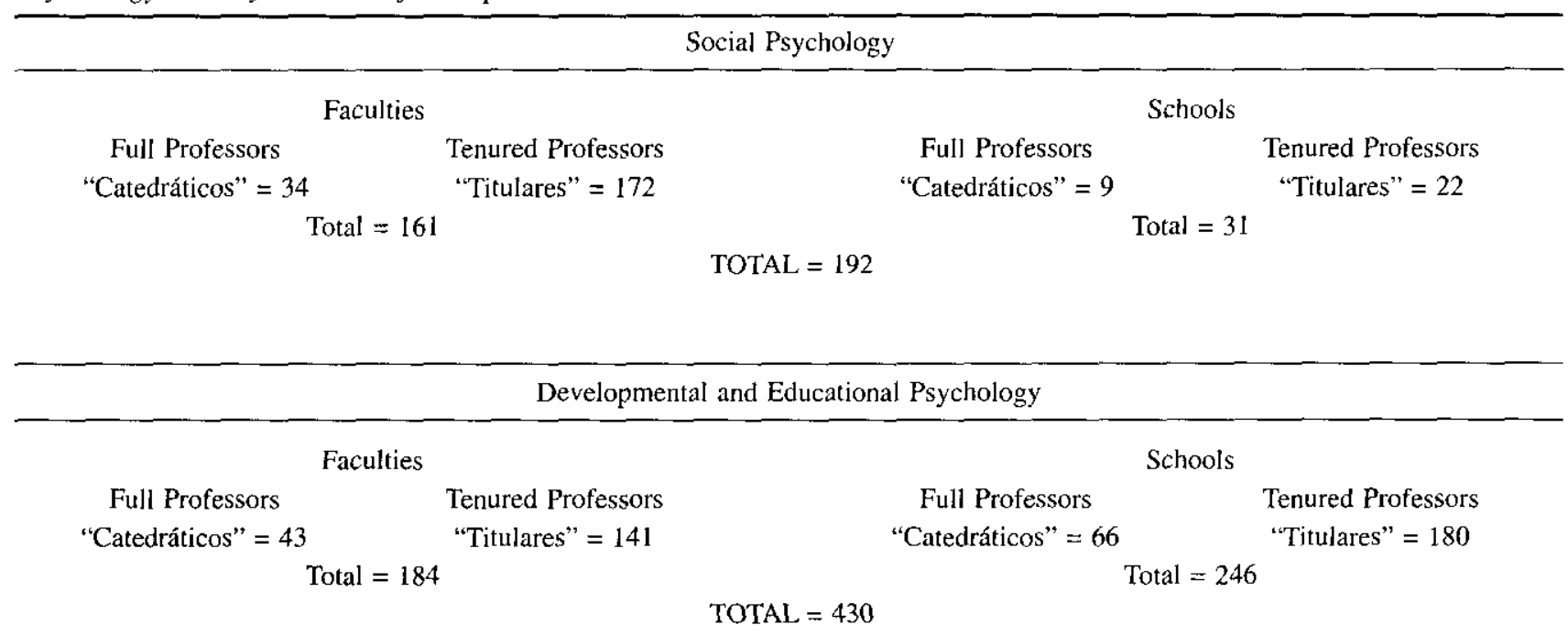

Personality, Assessment, and Psychological Treatments

\begin{tabular}{|c|c|c|c|}
\hline \multicolumn{4}{|c|}{ Personality, Assessment, and Psychological Treatments } \\
\hline \multicolumn{2}{|c|}{ Faculties } & \multicolumn{2}{|c|}{ Schools } \\
\hline $\begin{array}{c}\text { Full Professors } \\
\text { "Catedráticos" = } 37\end{array}$ & $\begin{array}{l}\text { Tenured Professors } \\
\text { "Titulares" }=204\end{array}$ & $\begin{array}{c}\text { Full Professors } \\
\text { "Catedráticos" }=4\end{array}$ & $\begin{array}{c}\text { Tenured Professors } \\
\text { "Titulares" }=24\end{array}$ \\
\hline \multicolumn{2}{|c|}{ Total $=241$} & \multicolumn{2}{|c|}{ Total $=28$} \\
\hline
\end{tabular}

$\begin{array}{ccccc}\text { Full Professors } & \text { Baculties } & \text { Basic Psychology } & \text { Schools } \\ \text { "Catedráticos" }=45 & \text { Tenured Professors } & \text { Full Professors } & \text { Tenured Professors } \\ \text { Total }=224 & \text { "Titulares" }=179 & \text { "Catedráticos" }=3 & \text { Total }=16\end{array}$

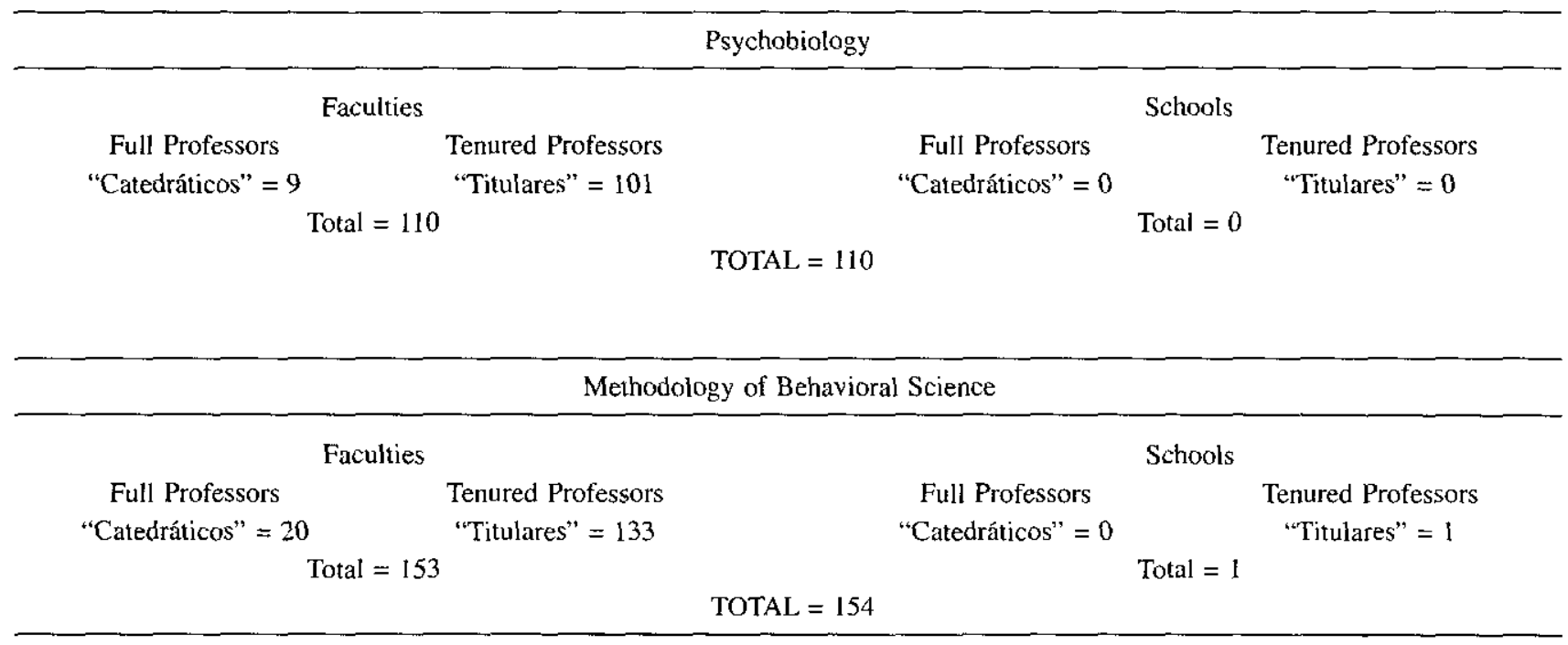


their area; others performed samplings to detect the possible more common errors; others reviewed the data they had received and asked for more information and carried out new searches in the cases that they suspected contained error's, etc.

After all this work, and to guarantee as much as possible that each and every one of the professors had an equal opportunity to make their possible research trend known, we undertook the third step. We decided to send a letter to each of the faculty members from all the areas, in which we included the information we had found in the various databases so that the professor could either ratify or rectify our findings. Thus, we offered all the professors the chance to conect the slightest error or bias that might have occurred in any of the previous steps. In one case only - the area of Developmental and Educational Psychology - the authors decided not to make use of the information we had found in the databases, because they thought it was not reliable enough, and they contacted the professors directly to ask them to provide all the data about their scientific production. Afterwards, these authors completed this information with that from the databases.

The fourth step consisted of preparing and writing each of the articles that make up this special issue. Obviously, in this last step, the authors' personal characteristics will necessarily come into play. Except for the basic structure of each work, which is common to all, the rest will depend on the author's specific style and decisions. As they are solicited works, the ultimate responsibility for the article lies with the authors.

I would like to point out here that the research trends mentioned in each article have a twofold classification criterion. The first criterion-academic affiliation- refers to the professor's official affiliation to each of the six institutionally valid areas in Spain, as seen in Table 1 . If a professor's classification within an area coincides entirely with his or her research trend, then, obviously, the trend will appear in that area. Otherwise, the second criterion -subject matter- will be applied to the research trend, and the trend will appear in the appropriate article that covers that subject matter. For example, if a professor is affiliated within the area of Social Psychology, but has worked in educational topics, then his or her research trend will appear in the article by the authors who are in charge of writing about this latter scientific field. In doubtful cases, the research trends were mentioned within the official affiliation area.

\section{Prior Reviews}

This study is contextualized within the growing interest in Spain to offer a synthesis of the current situation of psychology in our country, in order to achieve international dissemination. Within the last decade, I would like to highlight the review carried out by Prieto, FernatndezBallesteros, and Carpintero (1994), which appeared in the Annual Review of Psychology, and the review performed by several psychology faculty members and professionals for the special issue of the journal Applied Psychology: An Intemational Review, in 1994, Volume 43.

Although this current review shares with the former ones the general aim of international dissemination of Spanish psychology, everything else is different. Its purpose, given that it is more specific -research trends-, and the procedure: searching the different national and international databases, with the corresponding ratification or rectification by the affected parties, as was described in detail above.

\section{Current Context}

In order to comprebend any phenomenon, first, some of the context characteristics, which most certainly condition it, must be mentioned. In this section, I will describe the specific context of the psychology faculty members, and subsequently, the common context of any Spanish university faculty member.

\section{Specific Context}

Teaching. Most of these psychology faculty members teach their classes in one of the 24 psychology faculties of the 22 public universities that are shown in Table 2 .

Every year, all these professors must face more than 6,000 students who enroll for the first time in the Spanish public universities, as seen in the right column. Obviously, to these $1^{\text {st }}$-year students must be added the students from the remaining three or four courses, depending on the curriculum that is taught during the four or five academic courses.

Research: Spanish psychology journals. The most complete and current review of the evolution of Spanish psychology joumals during the second part of the $20^{\text {th }}$ century is probably the one writien by Alcaín and Ruíz-Gálvez (1998). In this review, we see that, as of the mid-century, which is when the first journals appeared, until the present time, more than 100 journals were published, although more than 30 have since disappeared. Approximately 20 are indexed in the PsycLIT databases of the APA and less than five are indexed in the Social Science Citation Index. Most of the journals, about $75 \%$, emerged in three large cities: Madrid, Barcelona, and Valencia, and were sponsored either by the universities or by the professional associations.

Only two, out of all of the journals still published, appear entirely in English: the European Joumal of Psychological Assessment and The Spanish Journal of Psychology. Currently, the first electronic journals are also starting to appear (Psychology in Spain, etc.).

\section{General Context}

Along with these more specific aspects regarding the psychology professors, it seems pertinent to show some other aspects that are common to all Spanish university faculty members. For this purpose, 1 will present an 
Table 2

Public Universities, Centers at which the Psychology Degree is Taught, Location, and Number of Seats Foreseen for 1999

\begin{tabular}{|c|c|c|c|}
\hline University & Center & Location & Seats (1999) \\
\hline Almería & Humanities and Educational Sciences Faculty & Almería & 250 \\
\hline Autónoma de Barcelona & Psychology Faculty & Cerdanyola & 410 \\
\hline Autónoma de Madrid & Psychology Faculty & Madrid & 445 \\
\hline Barcelona & Psychology Faculty & Barcelona & 610 \\
\hline Complutense de Madrid & Cardenal Cisneros & Madrid & 140 \\
\hline Complutense de Madrid & Psychology Faculty & Madrid & 600 \\
\hline Complutense de Madrid & San Pablo & Madrid & 120 \\
\hline Girona & Educational Sciences Faculty & Girona & 84 \\
\hline Granada & Psychology Faculty & Granada & 320 \\
\hline Islas Baleares & Philosophy and Arts Faculty & Palma de Mallorca & 110 \\
\hline Jaén & Humanities and Educational Sciences Faculty & Jaén & 200 \\
\hline Jaime I de Castellón & Human and Social Sciences Faculty & Castellón & 185 \\
\hline La Laguna & Psychology Faculty & La Laguna & 250 \\
\hline Málagà & Psychology Faculty & Málaga & 300 \\
\hline Miguel Hernández & Social and Judicial Sciences Faculty & Elche & 125 \\
\hline Murcia & Psychology Faculty & Espinardo & 230 \\
\hline UNED* & Psychology Faculty & Madrid & ** \\
\hline Oviedo & Psychology Faculty & Oviedo & 100 \\
\hline País Vasco & Psychology Faculty & San Sebastián & 300 \\
\hline Rovira i Virgili & Educational Sciences and Psychology Faculty & Tarragona & 105 \\
\hline Salamanca & Psychology Faculty & Salamanca & 230 \\
\hline Santiago de Compostela & Psychology Faculty & Santiago & 300 \\
\hline Sevilla & Psychology Faculty & Sevilla & 356 \\
\hline Valencia Estudi General & Psychology Faculty & Valencia & 500 \\
\hline
\end{tabular}

* Universidad Nacional de Educación a Distancia (Open University); ** = unlimited.

extensive study carried out with the aim of ascertaining the professors" opinion about the conditions in which they perform their teaching and researching functions (for more details -both methodological and conceptual-, see Fernández, 1997; Fernández \& Mateo, 1993, 1994; Fernández, Mateo, \& Muñiz, 1995; Mateo \& Fernández, 1995).

The data offered below are fruit of three different studies. carried out with an interval of three academic courses between them (1986/87, 1989/90, and 1992/93). The first, financed by the Consejo de Universidades, was performed with a representative sample of the Spanish universities. For this purpose, 800 faculty members from 11 universities were asked to fill in the Academic Setting Evaluation Questionnaire (ASEQ; Fernández \& Mateo, 1993), in its most extensive 69-item version. In the second research, funded by the Complutense University, a total of 2,547 professors participated, filling in the same assessment instrument, in its intermediate 59-item version. In the third research, financed by the University of Oviedo, 655 professors filled in the same questionnaire as had their counterparts from the Complutense University.

It must be pointed out that the questionnaire used has undergone three kinds of modifications from 1986 till the present time, to favor methodological rigor as well as to meet user requirements: item reduction, incorporation of some new items, and modification of some items to clarify comprehension. This is why only 59 items are presented in the tables displayed below (the common denominator of the three studies), some cells are empty (due to the later incorporation of new items) and there are asterisks in some cells (that indicate slight modifications in the items).

The 59 items are grouped into theoretical nuclei to match psychometric criteria (different factors or clusters), as well to favor clear interpretation.

Results. In Table 3 are displayed the data about the first relevant nucleus: satisfaction with the university institutions.

At first glance, one can see that the professors' evaluation of this nucleus is not excessively positive in the three studies. The values assigned to the 15 items do not exceed the positive cut-off point (4), the theoretical mean of the rating scale, which ranges from 1 to 7 ( 1 always indicates the highest degree of agreement with the content of each item, and 7 the lowest).

Doubtless, this first general overview can be completed with other more specific interpretations, in order to actualize and enrich it. For instance, one can note the low and 
Table 3

Satisfaction with University Institutions

\begin{tabular}{|c|c|c|c|c|}
\hline \multirow[b]{2}{*}{ Item No. } & & \multicolumn{3}{|c|}{ Means on a 1 - 7 Rating Scale } \\
\hline & & $1986-87$ & & $1992-93$ \\
\hline 1. & The material conditions in which I carry out my work are satisfactory. & 3.0 & 3.2 & 39 \\
\hline 2. & Economically, it is made possible for me to carry out my research. & 2.4 & 2.6 & 3.2 \\
\hline 3. & I am given institutional help to publish my studies, & 2.8 & 2.8 & 3.3 \\
\hline 4. & I consider my university teaching activities to be fairly paid. & 2.4 & 2.8 & 3.4 \\
\hline 11. & There are clear criteria for evaluating research activities. & 2.2 & 2.4 & 2.5 \\
\hline \multirow[t]{2}{*}{12.} & There is agreement between my expectations of what a teacher should & & & \\
\hline & be and what she/he, in fact, is. & 2.8 & 3. 1 & 3.3 \\
\hline 13. & Society appreciates the work done by university teachers. & 2.6 & 2.8 & 3.1 \\
\hline 14. & University institutions stimulate me to improve as a teacher. & 2.4 & 2.5 & 2.5 \\
\hline 16. & I have been prepared institutionally to carry out my duties as a researcher suitably. & 2.5 & 2.7 & 2.8 \\
\hline 17. & The prospects for my work as a teacher are favorable. & 2,9 & 3.2 & 3.4 \\
\hline 18. & Future prospects as a university researcher are favorable. & 2.7 & 3.1 & 3.2 \\
\hline 19. & 1 find adequate institutional aid to solve my professional problems as a teacher. & 2.8 & 2.9 & 3.1 \\
\hline 20. & I have sufficient time to carry out my research duties. & 3.1 & 3.2 & 3.3 \\
\hline 22. & University institutions encourage my research activity. & 2.4 & 2.8 & 2.8 \\
\hline 34. & \multicolumn{2}{|l|}{ I feel satisfied with the conditions offered by university institutions for performing my duties. } & 3.0 & 3.6 \\
\hline
\end{tabular}

Note $* \mathrm{CU}=$ Study carried out in one third of the Spanish universities for the Council of Universities.

+ CUM $=$ Complutense University of Madrid.

$\wedge$ UO $=$ University of Oviedo289 RVPl-1.

Table 4

Intradepartmental Social Climate and Relations with Students

\begin{tabular}{|c|c|c|c|c|}
\hline \multirow{2}{*}{\multicolumn{2}{|c|}{$\begin{array}{l}\text { Intradepartmental Social Climate } \\
\text { Item No. }\end{array}$}} & \multicolumn{3}{|c|}{ Means on a 1 - 7 Rating Scale } \\
\hline & & \multirow{2}{*}{$\frac{1986-87}{4.7}$} & \multirow{2}{*}{$\frac{1989.90}{4.5}$} & \multirow{2}{*}{$\frac{1992-93}{4.3}$} \\
\hline 5. & I feel supported by my colleagues in the activities I carry out as a teacher. & & & \\
\hline 6. & The academic context encourages my professional work. & *3.5 & 3.3 & 3.4 \\
\hline 7. & There is satisfactory academic communication among the members of my department. & 3.8 & 3.7 & 3.1 \\
\hline 8. & My human relationship with my departmental colleagues favors my academic activity. & $* 4.1$ & 4.2 & 3.7 \\
\hline 26. & $\begin{array}{l}\text { The teachers of the department cooperate in the preparation } \\
\text { of the department's research programs. }\end{array}$ & 3.9 & 3.7 & 3.3 \\
\hline 33. & I feel supported by my departmental colleagues in my research. & 4.1 & 3.8 & 3.6 \\
\hline 35. & I find an intradepartmental climate conducive to carrying out my functions as a teacher. & 3.5 & 3.4 & 3.3 \\
\hline \multicolumn{5}{|c|}{ Relationship with Students } \\
\hline 21. & Students show interest in the subject that I teach. & 4.4 & 4.6 & 4.4 \\
\hline 24. & Students ask about their doubts in the time set aside to receive them. & 3.8 & 3.7 & 3.2 \\
\hline 25. & Student's opinions are taken into account with the aim of improving my teaching. & 4.6 & 4.8 & 4.7 \\
\hline 27. & $\begin{array}{l}\text { Each year I take students" opinions into account when working } \\
\text { out my teaching methodology. }\end{array}$ & 4.7 & 5.2 & 4.9 \\
\hline 28. & I adapt my teaching to the particular demands of each group of students. & 4.9 & 5.3 & 5.1 \\
\hline 29. & Students' work adapts easily to the demands of my subject. & 4.2 & 4.5 & 4.4 \\
\hline 32. & Students show differential evaluation of each teacher according to his/her teaching quality. & 4.2 & 4.9 & 4.6 \\
\hline 36. & Students take an active part. & 3.6 & 3.3 & 2.9 \\
\hline
\end{tabular}

Note. ${ }^{*}=$ slight modification in the elaboration of this item in this study. 
relatively uniform rating of certain items, such as the $11^{\text {th }}$ (there are clear criteria for evaluating research activities: $2.2,2.4,2.5$ ), the $14^{\text {th }}$ (university institutions stimulate me to improve as a teacher: $2.4,2.5,2.5$ ), and the $16^{\text {th }}$ (I have been prepared institutionally to carry out my duties as a researcher suitably: $2.5,2.7,2.8$ ). One can also observe a certain evaluation distance between the last research and the first two, as seen in the items 1 (the material conditions in which I carry out my work are satisfactory: $3.0,3.2,3.9$ ), 2 (economically, it is made possible for me to carry out my research: $2.4,2.6,3.2$ ), and 4 (I consider my university teaching activities to be fairly paid: $2.4,2.8,3.4)$.

In Table 4 are shown the data about two important nuclei: intradepartmental social climate and relationship with the students.

Concerning the social climate, it can be seen that, although the general assessment is a bit more positive than the one reflected in the first nucleus, the negatively evaluated aspects predominate over those that obtained a satisfactory score. Only one item, number 5 (I feel supported by my colleagues in the activities I carry out as a teacher) was rated higher than the cut-off point or theoretical mean in the three studies. Two other items, numbers 8 (my human relationship with my departmental colleagues favors my academic activity) and 33 (I feel supported by my departmental colleagues in my research) showed values around the theoretical mean of the rating scale, when the results of the three studies are taken into account conjointly. For the remaining items, the assessment is fairly negative in all three cases. This first assessment is clearer when taking into account that appraisal of social climate seems to decline as time goes by.

With regard to the relations with students, the data seem to reflect a global positive evaluation, both from the comparative perspective concerning the two important previous nuclei, and from the analysis itself, because in the majority of the items, the empirical means exceed the theoretical means of the rating scale in the three studies. Nevertheless, in two items, numbers 24 (students ask about their doubts in the time set aside to receive them) and 36 (students take an active part), the values are below the cut-off point.

In Table 5 are displayed the data about the especially relevant nucleus of selection and promotion of faculty members, as well as the block of weighting items.

Here, a series of significant and relevant phenomena for any university policy are discovered. First, current professor selection and promotion systems do not satisfy the majority of the Spanish university faculty members. Second, the introduction of "objective" evaluation systems seems to be essential. Third, labor contracts may be an alternative that could be combined with the current system of competitive examinations ("oposición") to achieve tenure.

Insofar as the weighting items are concerned, the evident similarity of the assessment profile in the three studies can be seen. The well-rated items are just as concordant as the poorly rated items. For instance, the three last items, numbers 43 (I teach the subject for which I really feel best prepared: $5.5,6.0,5.6$ ), 44 (I can approach the subject from the perspective which I consider most appropriate: 5.3, 6.0, 5.8),

Table 5

Selection and Promotion of Faculty Members and Weighting Items

\begin{tabular}{|c|c|c|c|c|}
\hline \multirow{2}{*}{\multicolumn{2}{|c|}{$\begin{array}{l}\text { Selection and Promotion } \\
\text { Item No. }\end{array}$}} & \multicolumn{3}{|c|}{ Means on a I - 7 Rating Scale } \\
\hline & & \multirow{2}{*}{$\frac{1986-87}{2.6}$} & \multirow{2}{*}{$\frac{1989-90}{2.7}$} & \multirow{2}{*}{$\begin{array}{c}1992-93 \\
2.7\end{array}$} \\
\hline 9. & Teacher selection systems are suitable. & & & \\
\hline 10. & Teaching activity control systerns are appropriate. & $* 2.3$ & 2.8 & 2.8 \\
\hline 15. & Teacher promotion syștems are appropriate & 2.4 & 2.4 & 2.4 \\
\hline 23. & The civil-service system is appropriate for carrying out teachers' functions. & 3.0 & 3.1 & 3.5 \\
\hline 30 . & Labor contracts would enable teachers' duties to be performed better. & 4.2 & 3.9 & 3.7 \\
\hline 31. & Some "objective" system of evaluatiot of each teacher"s research work is necessary. & 5.4 & 5.2 & 5.5 \\
\hline 37. & Present faculty selection and promotion systems are adequate. & & 2.5 & 2.6 \\
\hline
\end{tabular}

Weighting Items

38. Students question the possible usefulness of the contents imparted.

39. Teacher evaluation carried out by students provides the institution with useful information.

40. The numbers of students assigned is appropriate for them to be prepared professionally.

41. The students propose alternative methods of giving the class.

42. There is intradepartmental cooperation in the programming of teaching.

43. I teach the subject for which I really feel best prepared.

44. I can approach the subject from the perspective which I consider most appropriate.

45. The training received to work as a teacher is sufficient. 
Table 6

Performance of Institutional Services

\begin{tabular}{|c|c|c|c|c|}
\hline \multirow{2}{*}{\multicolumn{2}{|c|}{ Item No. }} & \multicolumn{3}{|c|}{ Means on a $1-7$ Rating Scale } \\
\hline & & \multirow{2}{*}{$\frac{1986-87}{4.3}$} & \multirow{2}{*}{$\frac{1989-90}{4.6}$} & \multirow{2}{*}{$\frac{1992-93}{4.2}$} \\
\hline 46. & Performance of library. & & & \\
\hline 47. & Performance of laboratories. & 3.6 & 3.7 & 4.0 \\
\hline 48. & Performance of newspaper library. & 3.9 & 4.2 & 3.7 \\
\hline 49. & Performance of computerized equipment. & 3.8 & 3.5 & 4.2 \\
\hline 50 . & Performance of audiovisual equipment. & 3.1 & 3.3 & 3.8 \\
\hline 51. & Performance of secretarial services. & 4.8 & 4.6 & 5.0 \\
\hline 52. & Physical state of the building. & 3.3 & 3.3 & 4.1 \\
\hline 53. & Cultural activities organized by the institution. & 3.1 & 3.3 & 3.1 \\
\hline 54. & Performance of auxiliary staff (porters...). & 3.8 & 3.9 & 3.8 \\
\hline 55. & Performance of deanery. & 4.7 & 4.7 & 4.2 \\
\hline 56. & Performance of rectorate. & 3.6 & 4.4 & 4.1 \\
\hline 57. & Performance of sports facilities. & 3.3 & 3.8 & 3.7 \\
\hline 58. & Performance of dining rooms and coffee-shops. & 3.4 & 3.1 & 3.8 \\
\hline 59. & Performance of Ministry of Education and Science. & & 3.0 & 2.9 \\
\hline
\end{tabular}

and 45 (the training received to work as a teacher is sufficient: $5.1,5.0,4.5$ ) present extremely high values in all three studies, whereas three other items, numbers 40 (the number of students assigned is appropriate for them to be prepared professionally: $2.1,2.6,2.8$ ), 41 (the students propose alternative methods of teaching the class: $2.3,2.4,1.8$ ) and 42 (there is intradepartmental cooperation in the programming of teaching: $2.7,3.0,2.6$ ) show a fairly negative assessment.

The first two items of this block deserve special mention: item number 38 (students question the possible usefulness of the contents imparted: $4.1,4.2,4.0$ ) and number 39 (teacher evaluation carried out by students provides the institution with useful information: 4.0, 4.2, 3.5). Regarding the first, one should examine the extent to which the students' opinions were taken into account when elaborating the recently implemented new syllabuses. With reference to the second item, clear differences are observed between the last two studies. In the case of the Complutense University, the notion of the usefulness of students' evaluation for the institution seems to be gaining strength.

In Table 6 are shown the data about the performance of the institutional services.

Once again, the similarity of the assessment profile in the three studies is evident. The secretaries appear in all three studies at the positive extreme, and at the negative one, the "Ministerio de Educación y Ciencia" [Ministry of Education and Science] (in the two studies that included this item).

Comment. It would be very difficult to accurately appraise the scientific production of Spanish university professors without taking into account this detailed context, so typical of the Spanish university in general, and therefore, common denominator of the different psychology centers for a large part of the decade under study. This is especially true if one is logically tempted to compare this production with that achieved by other foreign universities.

\section{References}

Alcaín, M D., \& Ruíz-Gálvez, M. (1998). Evolución de las revistas españolas de psicología. Papeles del Psicólogo, 70, 35-42.

Ángel Baltanás, 1.C. (1999). Why Spanish science is at a standstill. Nature, 397, 558.

Dyson, F. (1997). Imagined words. Cambridge, MA: Harvard University Press.

Fernández, J. (1997). A Spanish evaluation model in higher education: Circular evaluation. Higher Education Management, 9, 71-84.

Fernández, J., \& Mateo, M.A. (1993). The development and factorial validation of the Academic Setting Evaluation Questionnaire. Educational and Psychological Measurement, 53, 425-435.

Fernández, J., \& Mateo, M.A. (1994). The circular evaluative process of higher education: A Spanish sample. In OECD (Ed.), Evaluation and the decision making process in higher education: French, German, and Spanish experiences (pp. 8394). Paris: OECD Publications.

Fernández, J., Mateo, M.A., \& Muñiz, J. (1995). Evaluation of the academic setting in Spain. European Journal of Psychological Assessment, 11, 133-137.

Mateo, M.A., \& Fernández, J. (1995). Evaluation of the setting in which university faculty carry out their teaching and research functions: The ASEQ. Educational and Psychological Measurement, 55, 329-334.

Prieto, J.M., Fernández-Ballesteros, R., \& Carpintero, H. (1994). Contemporary psychology in Spain. Annual Review of Psychology, 45, 51-78. 